\title{
CORRECTION
}

Open Access

\section{Correction to: Ochratoxigenic fungi and Ochratoxin A determination in dried grapes marketed in Tunisia}

\author{
Samir Chebil ${ }^{1}$, Wafa Rjiba-Bahri ${ }^{2}$, Souheib Oueslati ${ }^{1}$, Hanen Ben Ismail ${ }^{2}$, Anis Ben-Amar ${ }^{1}$ and Pantelis Natskoulis ${ }^{3 *}$
}

\author{
Correction to: Ann Microbiol 70, 38 (2020) \\ https://doi.org/10.1186/s13213-020-01584-7
}

In the original article (Chebil et al. 2020), two authors were missing from the author's list. Dr. Wafa Rjiba-Bahri and Dr. Hanen Ben Ismail have been added as co-authors for their contributions in designing the molecular biology work, conducting the laboratory work and drafting the article, and designing the study, respectively. Dr. Wafa Rjiba-Bahri and Dr. Hanen Ben Ismail declare no conflict of interest. The author's list in the original article has been updated, as well as the list of affiliations and the statement in the Authors' contributions.

\section{Author details}

'Laboratory of Plant Molecular Physiology, Centre of Biotechnology of Borj Cedria, B.P. 901 Hammam-Lif, 2050 Tunis, Tunisia. ${ }^{2}$ Laboratory of Alimentary Technology, National Agricultural Institute of Tunisia, 43, Charles Nicolle Avenue, 1082 Mahrajene City, Tunis, Tunisia. Institute of Technology of Agricultural Products, Hellenic Agricultural Organisation - DEMETER, $1 \mathrm{~S}$. Venizelou Str., 14123 Lykovrisi, Greece.

Published online: 30 September 2020

\section{Reference}

Chebil S et al (2020) Ochratoxigenic fungi and Ochratoxin A determination in dried grapes marketed in Tunisia. Ann Microbiol 70:38 https://doi.org/10. 1186/s13213-020-01584-7

*Correspondence: p.natskoulis@gmail.com

${ }^{3}$ Institute of Technology of Agricultural Products, Hellenic Agricultural

Organisation - DEMETER, 1 S. Venizelou Str., 14123 Lykovrisi, Greece

(c) The Author(s). 2020 Open Access This article is licensed under a Creative Commons Attribution 4.0 International License, which permits use, sharing, adaptation, distribution and reproduction in any medium or format, as long as you give appropriate credit to the original author(s) and the source, provide a link to the Creative Commons licence, and indicate if changes were made. The images or other third party material in this article are included in the article's Creative Commons licence, unless indicated otherwise in a credit line to the material. If material is not included in the article's Creative Commons licence and your intended use is not permitted by statutory regulation or exceeds the permitted use, you will need to obtain permission directly from the copyright holder. To view a copy of this licence, visit http://creativecommons.org/licenses/by/4.0/ 